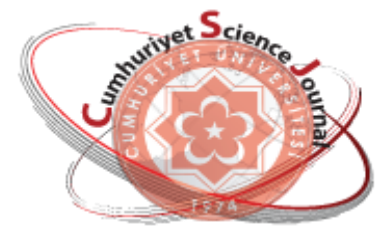

e-ISSN: $2587-246 X$

ISSN: $2587-2680$

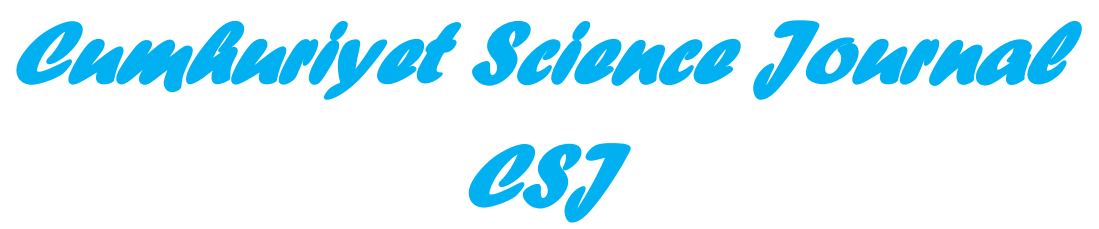

Cumhuriyet Sci. J., Vol.39-3(2018) 658-667

\title{
In vitro Antioxidant Properties of Novel Compound (1R, 2R) -1,2-bis- (5- (4- Hydroxynaphthalen-1-ylazo) - [1,3,4] Thiadiazol-2-YL) -Ethane- 1,2-Diole
}

\author{
Akif Evren PARLAK ${ }^{*}$, Pelin KOPARIR \\ ${ }^{1}$ Firat University, Vocational School of Keban, Elazig, TURKEY \\ ${ }^{2}$ Institute of Forensics, Department of Chemistry, Malatya, TURKEY
}

Received: 03.04.2018; Accepted: 22.05.2018

http://dx.doi.org/10.17776/csj.412123

\begin{abstract}
Thiadiazoles have a variety of biological activities depending on their substituents. This study aims to investigate the in vitro antioxidant properties of $1 R, 2 R$-1,2-bis- (5- (4-hydroxynaphthalen-1-ylazo) [1,3,4] thiadiazol-2-yl) -ethane- 1,2-diole novel compound. In this study, antioxidant activities were measured by different methods such as, DPPH radical scavenging activity, iron reducing power capacity, metal chelating activity and hydroxyl radical scavenging activity. As a result, it was determined that this new compound has effective antioxidant and free radical scavenging activity when compared to reference antioxidants such as BHT and $\alpha$-tocopherol.
\end{abstract}

Keywords: 1-3-4 Thiadiazol, antioxidant activity, radical scavenging activity, biological activities.

\section{$(1 R, 2 R)$-1,2-BIS- (5- (4-Hidroksinaftalin-1- İlazo) - [1, 3,4] Tiyadiazol-2- Diol Yeni Bileşiğinin İn vitro Antioksidan Özellikleri}

Özet: 1,3,4-Tiyadiazoller yapılarındaki gruplara bağlı olarak çeşitli biyolojik aktivitelere sahiptir. Bu çalışma, $(1 R, 2 R)$-1, 2-bis- (5- (4-hidroksinaftalin-1-ilazo) - [1, 3,4] tiyaiyazol-2-il) etan-1,2-diole yeni bileşiğinin in vitro antioksidan özelliklerini araştırmayı amaçlamaktadır. Bu çalışmada antioksidan aktiviteler; DPPH radikal temizleme aktivitesi, demir azaltma gücü kapasitesi, metal şelatlama aktivitesi ve hidroksil radikali temizleme aktivitesi gibi farklı yöntemlerle ölçüldü Sonuç olarak, bu yeni bileşiğin BHT ve $\alpha$-tokoferol gibi referans antioksidanlar ile karşılaştırıldığında etkili antioksidan ve serbest radikal süpürücü aktiviteye sahip olduğu belirlendi.

Anahtar Kelimeler: 1-3-4 tiadiazol, antioksidan aktivite, radikal süpürücü aktivite, biyolojik aktiviteler.

\section{INTRODUCTION}

Antioxidant defense systems are the defensive systems that work in the body to prevent the damages induced by reactive oxygen derivatives [1]. Antioxidants are becoming increasingly important as the role of antioxidants in the prevention of oxidative stress-induced degenerative and age-related diseases is being demonstrated by experimental, clinical and epidemiological studies [2,3].

Antioxidants are the systems that neutralize the destructive effects of free radicals. There are many enzymatic or nonenzymatic endogenous antioxidant defense mechanisms in the body to prevent the formation of reactive oxygen species (ROS and the damage they cause. In addition,

\footnotetext{
* Corresponding author. Email address: akifevren@firat.edu.tr

http://dergipark.gov.tr/csj @2016 Faculty of Science, Cumhuriyet University
} 
certain medicines, vitamins and synthetic food antioxidants may be considered as exogenous antioxidants [4].

It is envisaged that compounds having antioxidant activity may be used in the treatment or prevention of diseases resulting from deficiency of antioxidant defense system in the body. Complexes formed by metals and heterocyclic ligands are model compounds of metal-proteins and due to this fact, they are of particular interest in bioinorganic chemistry. Nitrogen-containing heterocyclic molecules constitutethe largest family of chemical components used in many natural products and biologically active drugs that are vital for improved life quality $[5,6]$.

The investigation of the pharmacological properties of inorganic and organometallic compounds and the chemical bases of their mechanism of action is very important for the initial stages of drug research [7].

Five-membered heterocyclic rings containing one sulfur and two nitrogen atoms are called "thiadiazoles". There are four isomers of thiadiazole as 1,2,3-thiadiazole, 1,2,4-thiadiazole, 1,2,5-thiadiazole and 1,3,4-thiadiazole. Among these isomers, 1,3,4-thiadiazoles are known as the compounds with the highest biological activity. [8].

1,3,4-Thiadiazoles have a variety of biological activities depending on their substituents. The compounds possessing 1,3,4-thiadiazole ring have anticonvulsant [9], antiinflammatory [10], antifungal [11], antimicrobial [12], antituberculosis [13], antihypertensive [14] , hypoglycemic [15], anticancer [16] and antibacterial activities [17], therefore, they are important in the synthesis of new drugs.

In this study, antioxidant activities, 2,2-diphenyl1-picrylhydrazyl (DPPH) radical scavenging activity, iron reducing power capacity, metal chelating activity and hydroxyl radical scavenging activity of first-time synthesized $(1 R, 2 R)$-1,2-bis- (5- (4-Hydroxynaphthal-1- ylazo) - [1,3,4] thiadiazol-2-yl) -ethyl-1,2 diol compund were investigated by four different methods.

\section{MATERIAL AND METHODS}

\subsection{Chemicals}

The free radical scavenging activity assay 1,1Diphenyl 2-picryl hydrazyl (DPPH) was purchased from Sigma Aldrich, standard antioxidant Butylhydroxytoluene (BHT) and $\alpha$ tocopherol were purchased from Fluka. Chemical solutions (Dipotassium hydrogen phosphate, potassium dihydrogen phosphate, DMSO, methanol, ethanol, potassium ferricyanide, potassium persulfate, trichloroacetic acid (TCA), iron (III) chloride) were obtained from Merck (Darmstadt, Germany).

\subsection{Instrumentals}

Absorbance measurements in antioxidant studies were performed with a UV-Vis spectrophotometer: Shimadzu UV-1700 instrument. The brands of the devices used were as follows: $\mathrm{pH}$ meter Hanna HI221, precision balance Denver TP 323, magnetic stirrer KARHBasic, vortex IKA, shaking water tank Memmert VNB14, centrifuge Hettich 320.

\subsection{Antioxidant Activity Methods}

The compound $(1 R, 2 R)$-1,2-Bis- (5- (4Hydroxynaphthalen-1-ylazo) - [1,3,4] Thiadiazol2-yl) -Ethane-1,2-Diol was firstly synthesized by Metin Koparır et al. [18] in Organic Chemistry Laboratory in the Department of Chemistry, Faculty of Arts and Science, Firat University [18]. They synthesized $(1 R, 2 R)$-1,2-bis-(5-amino1,3,4-thiadiazol-2-yl)ethane-1,2-diol compound by using $2 R, 3 R)-(+)$-Tartaric acid as starting compound. Then the diazo component 3 was obtained from 2 and 1-naphthol. [figure 1]. In addition, the structures of the synthesized compounds 2 and 3 were confirmed by elemental analyses, IR, ${ }^{1} \mathrm{H}-\mathrm{NMR}$, and ${ }^{13} \mathrm{C}-\mathrm{NMR}$ spectra [18]. The test compound $(1 R, 2 R)-1,2-\mathrm{Bis}-(5-(4-$ hydroxynaphthalen-1-ylazo)-[1,3,4]thiadiazol-2yl)-ethane-1,2-diol (encoded in 3, in figure 1) 
was dissolved in a suitable solvent Dimethyl sulphoxide (DMSO).

The dissolved derivative was diluted to different concentrations using the same solvent (DMSO)

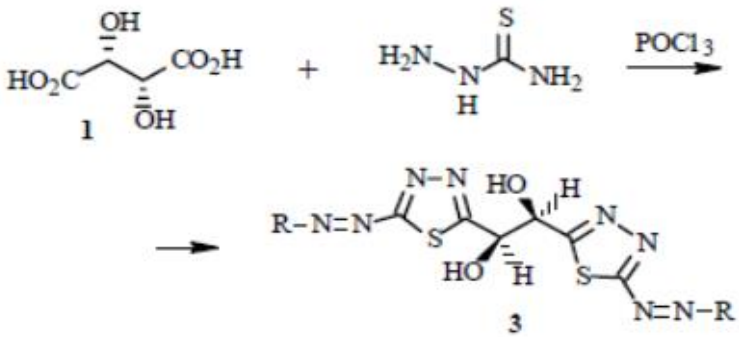

and the antioxidant activities were examined using the various methods listed below.

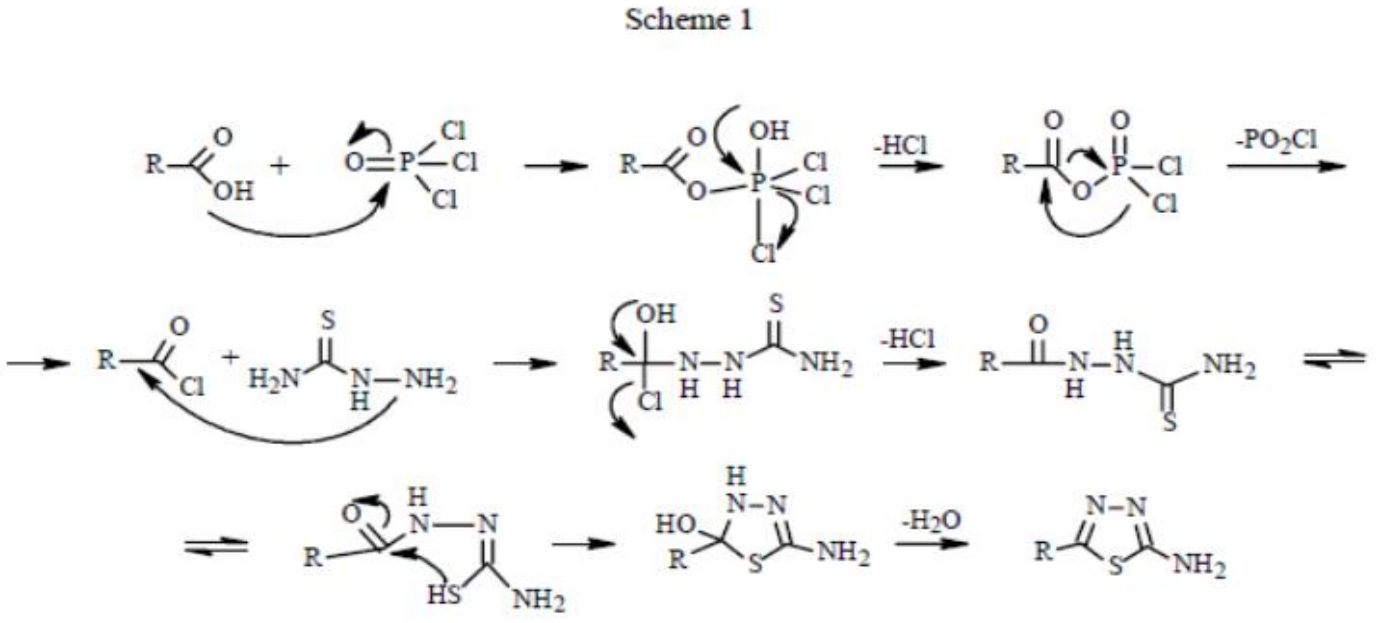

Scheme 2

Figure 1. Synthesis and mechanism of test compound [18].

\subsubsection{Determination of DPPH free radical scavenging activity}

Free radical scavenging activity assay of the compound was performed with a minor modification according to the Blois method (1958) using 1,1-Diphenyl 2-picryl hydrazyl (DPPH) [4]. Reagents used were: $0.1 \mathrm{mM} \mathrm{DPPH}$ and $\quad \alpha$-tocopherol $\quad(1 \quad \mathrm{mg} / \mathrm{ml})$, Butylhydroxytoluene (BHT) $(1 \mathrm{mg} / \mathrm{ml})$.

The test compound used in the study was dissolved in DMSO as $1 \mathrm{mg} / \mathrm{mL}$. The test compound and standards were transferred to the test tubes in the order of 50,100,250 $\mathrm{g} / \mathrm{ml}$, respectively. $1 \mathrm{~mL}$ of the stock DPPH solution was then added to each sample tube. The tubes were incubated for 30 minutes at room temperature and in darkness. After incubation,

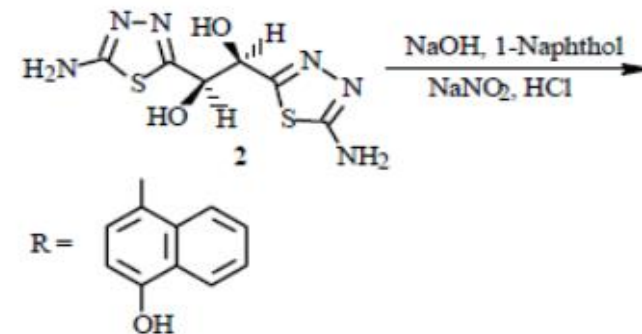

$\mathrm{OH}$ 


\subsubsection{Metal Chelating Activity}

The metal chelating activities of the test compound were measured according to the method of Dinis et al. [19]. For this procedure, $0.4 \mathrm{~mL}$ of samples from different concentrations of test compound $(50,100,250 \mu \mathrm{g} / \mathrm{mL})$ were added to $2 \mathrm{mM}$ and $0.05 \mathrm{~mL}$ of $\mathrm{FeCl}_{2}$ solution. The reaction was initiated by the addition of 0.2 $\mathrm{mL}$ and $5 \mathrm{mM}$ ferrozine solution. After vortexing the solution vigorously, it was left to stand at room temperature for $10 \mathrm{~min}$. After incubation, the absorbance at $562 \mathrm{~nm}$ was recorded against the residual blank solution without ferrozine. As thecontrol, the remaining solution was used without the test compound. To compare metal chelating activities, BHT and $\alpha$-tocopherol were used at the same concentration as the standard antioxidants.

Each measurement was repeated 3 times and the averages were calculated. In this method, low absorbance value is considered as high metal chelating activity. Percent metal chelating activity is calculated from the following formula;

$\%$ metal cheating activity $=\left[\left(\mathrm{A}_{0}-\mathrm{A}_{1}\right) / \mathrm{A}_{0}\right] \times 100$

$\mathrm{A}_{0}=$ Control absorbance

$\mathrm{A}_{1}=$ Absorbance of test compound and / or standards

\subsubsection{Iron Reduction Activity}

Iron reduction activity of the test compound was investigated based on $\mathrm{Fe}+3$ to $\mathrm{Fe}+2$ transformation by following Oyaizu method [20]. $1 \mathrm{~mL}$ of each tube was taken from DMSOdissolved samples $(50,100,250 \mu \mathrm{g} / \mathrm{mL})$ of the test compound at different concentrations. 2.5 $\mathrm{mL}$ of $0.2 \mathrm{M}$ phosphate buffer $(\mathrm{pH}=6,6)$ and 2.5 $\mathrm{mL}$ of $1 \%$ potassium ferrocyanide (K3 $[\mathrm{Fe}$ $\left(\mathrm{CN}_{6}\right)$ ] were added to each tube and the tubes were incubated at $50^{\circ} \mathrm{C}$ for $20 \mathrm{~min}$. After this procedure, $2.5 \mathrm{~mL}$ of $10 \%$ trichloroacetic acid (TCA) was added to the reaction mixtures. The mixtures were centrifuged at $2000 \mathrm{rpm}$ for 10 min. $2.5 \mathrm{~mL}$ were taken from the supernatant and after addition of $2.5 \mathrm{~mL}$ of distilled water and $0.1 \mathrm{~mL}$ of $0.5 \mathrm{~mL}$ of $\mathrm{FeCl} 3$, absorbance was measured at $700 \mathrm{~nm}$. DMSO was used as the blind. For the control, a reactive DMSO mixture without the compound was used. BHT and $\alpha$ tocopherol were the standard antioxidants, were used at the same concentration to compare the reduction activity. Each measurement was repeated 3 times and the averages were calculated. In this method, high absorbance value is considered as high reducing activity.

\subsubsection{Scavenging activity of hydroxyl radical with deoxyribose degradation}

The method based on the capture of nonenzymatic, hydroxyl radicals formed by Deoxyribose degradation was carried out with some modifications (Halliwell et al., 1987) [21]. Reaction mixture; $50 \mu \mathrm{L}$ of samples dissolved in DMSO at different concentrations (50, 100, 250 $\mu \mathrm{g} / \mathrm{ml})$ were taken and $150 \mu \mathrm{L}$ deoxyribose $(200$ $\mathrm{mM} 5 \mathrm{~mL}), 60 \mu \mathrm{L}$ FeSO $4.7 \mathrm{H}_{2} \mathrm{O}(20 \mathrm{mM} 50$ $\mathrm{mL}), 30 \mu \mathrm{L}$ EDTA $(10 \mathrm{mM} 50 \mathrm{~mL}), 150 \mu \mathrm{L}(500$ $\mathrm{mM} 5 \mathrm{~mL}$ ) were added and the mixture was mixed with $2.5 \mathrm{~mL}$ of $\mathrm{KH}_{2} \mathrm{PO}_{4}$ buffer (pH: 7.4) to a final volume of $3 \mathrm{~mL}$ and vortexed thoroughly.

$1 \mathrm{~mL}$ of $10 \%$ TCA and $1 \mathrm{~mL}$ of $2.0 \%$ TBA were added to the tubes kept at $37^{\circ} \mathrm{C}$ incubator for 1 hour. Samples heated at $100^{\circ} \mathrm{C}$ for $15 \mathrm{~min}$ in a hot water bath were subsequently exposed to room temperature, their absorbance at $532 \mathrm{~nm}$ wavelength against tampon was recorded. To compare the hydroxyl trapping activity, the standard antioxidant BHT and $\alpha$-tocopherol were used at the same concentration instead of the sample.

$\% \mathrm{OH}$ radical scavenging activity $=\left[\left(\mathrm{A}_{0}-\mathrm{A}_{1}\right) /\right.$ $\left.\mathrm{A}_{0}\right] \times 100$

The absorbance of the $\mathrm{A}_{0}$ control was taken as the absorbance of the $A_{1}$ test compound / standard. 


\section{RESULTS AND DISCUSSION}

Previous studies have indicated that a single method can not be sufficient to determine antioxidant activity, and therefore multiple methods are required to assess antioxidant activity [22,23]. Due to this fact, antioxidant activities of the synthesized compounds have been investigated by different methods.

The principle of the DPPH method is based on the reduction of colored free radical 1,1-Diphenyl 2-picryl hydrazyl radical (DPPH) by free radical scavengers. DPPH is a stable, red colored free radical. When free radicals are eliminated by antioxidant compounds, the color turns from red to yellow. The decrease in the absorbance of the reaction mixture at $517 \mathrm{~nm}$ indicates increased antioxidant effect in the free radical scavenging activity. The reduction ability of DPPH radicals was determined by absorbance reduction at 517 $\mathrm{nm}$ induced by antioxidants and percent inhibition values were calculated. The findings obtained are given in Table 1 .

Table 1. Scavenging effect of test compound, $\alpha$-tocopherol and BHT at different concentrations $(50-100-250 \mu \mathrm{g} / \mathrm{mL})$, values are expressed as mean $\pm \mathrm{SD}$.

\begin{tabular}{cccc}
\hline DPPH \% Inhibition & $\mathbf{5 0} \boldsymbol{\mu g} / \mathbf{m L}$ & $\mathbf{1 0 0} \boldsymbol{\mu g} / \mathbf{m L}$ & $\mathbf{2 5 0} \boldsymbol{\mu g} / \mathbf{m L}$ \\
\hline Test Compound & $67,8 \pm 0.21$ & $69,1 \pm 0.02$ & $73,3 \pm 1.2$ \\
$\alpha$-Tocopherol & $73,4 \pm .0 .01$ & $72,4 \pm 0.01$ & $76,7 \pm 1.03$ \\
BHT & $34,2 \pm 0.01$ & $43,7 \pm 0.1$ & $54,3 \pm 0,49$ \\
\hline
\end{tabular}

As indicated by the table, the test compound showed better activity than the standard BHT. On the other hand, the test compound has a lower activity to standards $\alpha$-tocopherol. Accordingly, it can be said that the test compound possesses high radical scavenging activity. This result may show that our test compound has good activity as a hydrogen donor because the effect of antioxidants on DPPH radical cleavage is possibly attributed to their hydrogen donor capabilities [24]. DPPH is a stable, free radical and accepts an electron or hydrogen radical to become a stable diamagnetic molecule [25].

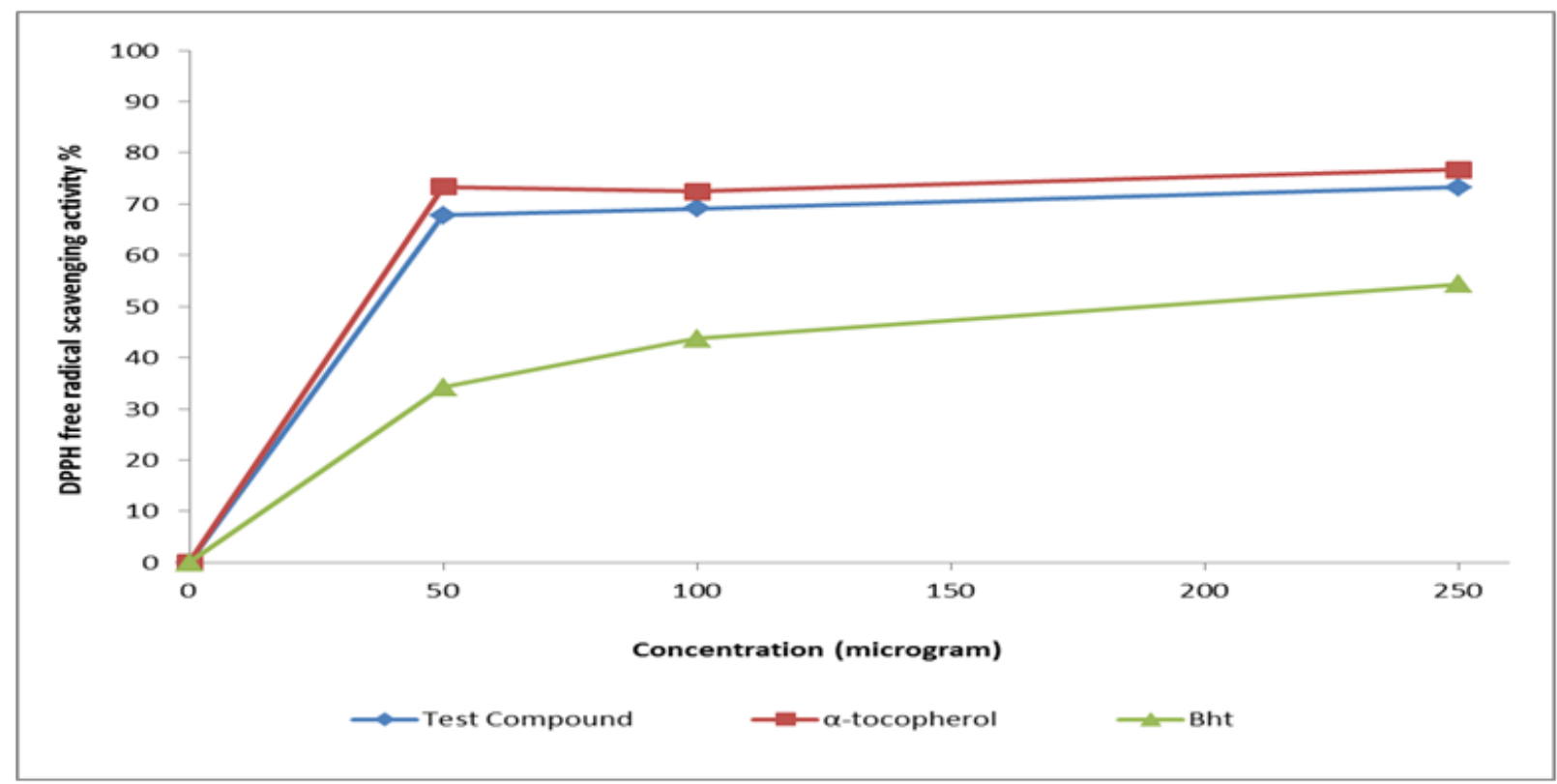

Figure 2. Comparison of $\%$ free radical scavenging activity of test compound and standard antioxidant compounds such as BHT and $\alpha$-tocopherol at the concentrations $(50-100-250 \mu \mathrm{g} / \mathrm{mL})$. 
The reduction power of a compound may be indicative of its high potential antioxidant power [26]. The $\mathrm{Fe}^{3+} /$ ferricyanide complex is reduced to the ferrous form as a result of reducing agents such as antioxidant substance content of antioxidant samples. [27].

The antioxidant activity of a possible antioxidant substance has been linked to various factors; prevention chain initiation, binding of transition metal ion catalyst, decomposition of peroxides, prevention of continued hydrogen abstraction, reductive capacity and radical scavenging [28].
Iron reduction activity of the test compound was evaluated as the absorbance against the concentration and the activities were compared with those of BHT and $\alpha$-tocopherol. In this method, high absorbance value is considered as high reducing power. It was found that although absorbance value of the test compound was lower than that of BHT and $\alpha$-tocopherol but test compound's iron reduction activity was similar to the activity level of BHT and $\alpha$-tocopherol. Accordingly, it can be said that the test compound has moderate iron reduction activity.

Table 2. Iron reducing power of test compound and standarts. Absorbance of 50, 100 and $250 \mu \mathrm{g} / \mathrm{ml}$ of test compound and standart antioxidants at $700 \mathrm{nM}$, values are expressed as mean $\pm \mathrm{SD}$.

\begin{tabular}{llll}
\hline Groups & $\mathbf{5 0} \boldsymbol{\mu g} / \mathbf{m L}$ & $\mathbf{1 0 0} \boldsymbol{\mu g} / \mathbf{m L}$ & $\mathbf{2 5 0} \boldsymbol{\mu g} / \mathbf{m L}$ \\
\hline Test Compound & $0,21 \pm 0.02$ & $0,33 \pm 0.01$ & $0,69 \pm 0.02$ \\
$\alpha$-tocopherol & $0,36 \pm 0.06$ & $0,42 \pm 0.01$ & $0,78 \pm 0.02$ \\
BHT & $0,42 \pm 0,01$ & $0,66 \pm 0,02$ & $1,27 \pm 0,02$ \\
\hline
\end{tabular}

These values are given in Table 2 and Figure 3, the reducing power of the test compound and shown. As the concentration of the test standards (BHT and $\alpha$-tocopherol) using the compound increased, the reduction activity also potassium ferricyanide reduction method is

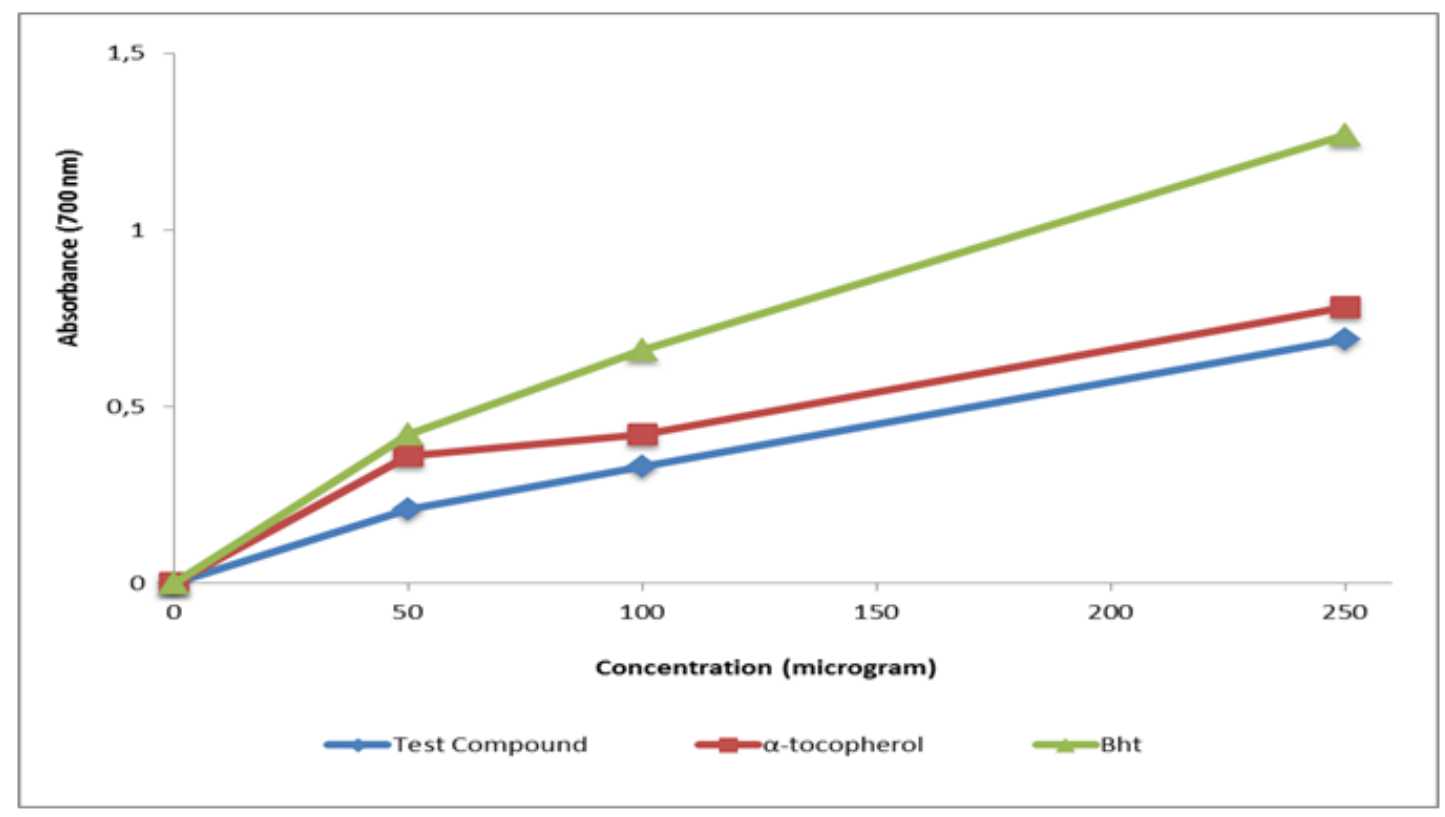

Figure 3. Comparison of reducing power capability of test compound and standard antioxidant compounds such as BHT and $\alpha$ tocopherol, at the concentrations $(50-100-250 \mu \mathrm{g} / \mathrm{mL})$. 
The following order shows the reducing power of the compounds and standards at maximum concentration $(250 \mu \mathrm{g} / \mathrm{ml})$ : BHT $>\alpha$-tocopherol $>$ Test compound.
The data obtained from the metal chelate activity test of the synthesized compounds are given in Table 3. The metal chelating activities of the test compound and standard are given as \% inhibition.

Table 3. Metal chelating activity of test compound, $\alpha$-tocopherol and BHT at different concentrations (50-100-250 $\mu \mathrm{g} / \mathrm{mL})$.

\begin{tabular}{lccc}
\hline Groups & $\mathbf{5 0} \boldsymbol{\mu g} / \mathbf{m L}$ & $\mathbf{1 0 0} \boldsymbol{\mu g} / \mathbf{m L}$ & $\mathbf{2 5 0} \boldsymbol{\mu g} / \mathbf{m L}$ \\
\hline Test Compound & $58,12 \pm 0.12$ & $66,10 \pm 1.49$ & $69,13 \pm 1.12$ \\
BHT & $52,78 \pm 1.46$ & $63,26 \pm 2.11$ & $68,18 \pm 2.19$ \\
$\alpha$-tocopherol & $61,25 \pm 2,01$ & $68,42 \pm 3,12$ & $74,68 \pm 2,52$ \\
\hline
\end{tabular}

The new test compound was found to show lower activity than the $\alpha$-tocopherol and higher activity than the standard antioxidant BHT, which indicate that the new compound has moderate metal chelating activity. In Figure 4, the ferrous ion chelating activities of the compound and standards are demonstrated. Figure 4 shows that with the increase in the concentration, metal chelating activity of the test compounds also increases. The chelating activity of the test compound and standarts were in the following order at maximum concentration $(250 \mu \mathrm{g} / \mathrm{mL}): \alpha$ -tocopherol > test compound > Bht respectively.
Metal chelating activity so important that reduced the catalyzing transition metal concentration in lipid peroxidation. It has been reported that chelating agents are useful as secondary antioxidants because they reduce the redox potential and thus stabilize the oxidized form of the metal ion [29]. The production of radicals can cause lipid peroxidation, protein modification and DNA damage. Chelating agents may not trigger metal ions and may possibly prevent metal-dependent processes [30].

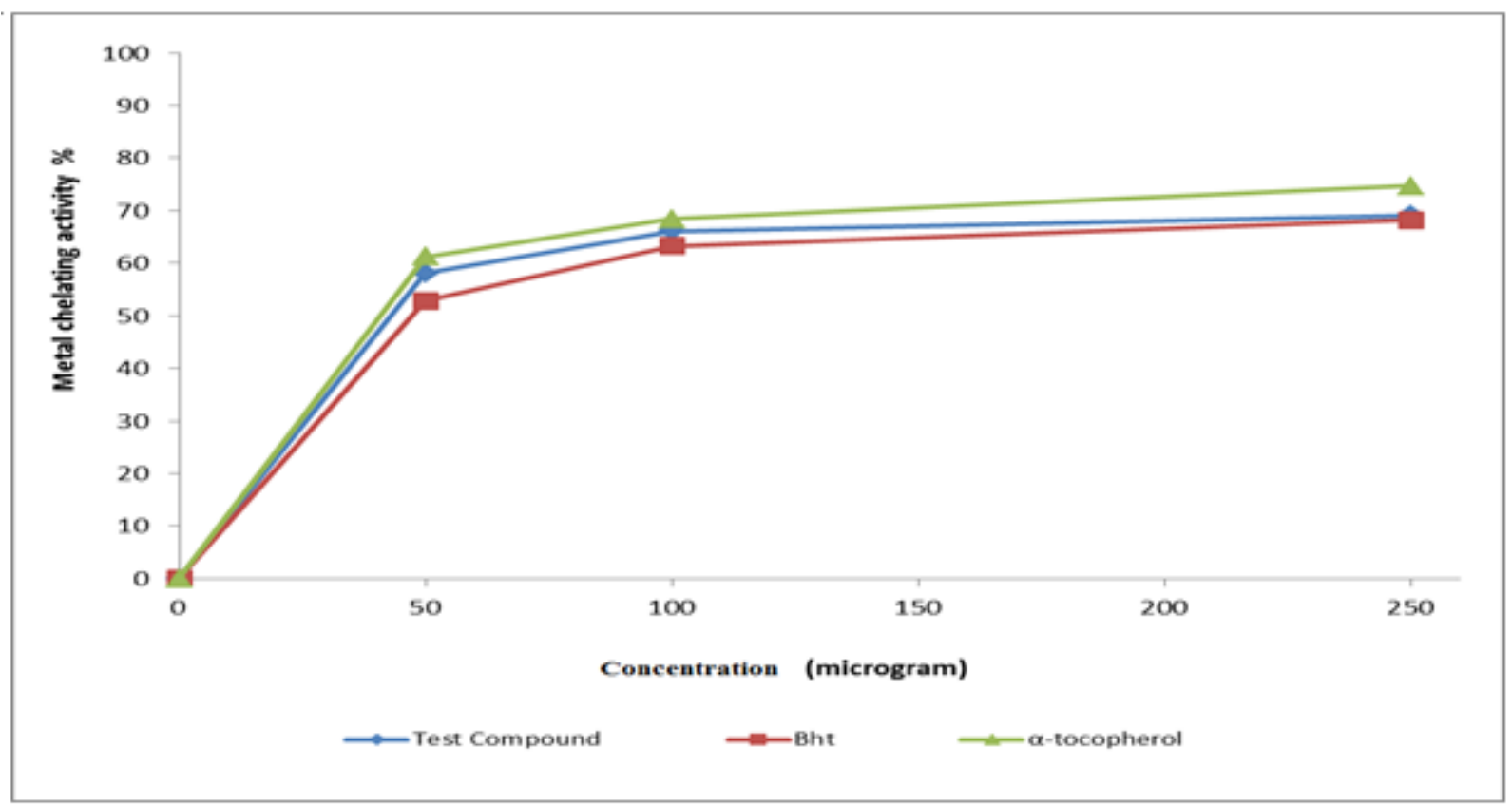

Figure 4. Comparison of metal chelating activity of test compound and standard antioxidant compounds such as BHT and $\alpha$ tocopherol, at the concentrations $(50-100-250 \mu \mathrm{g} / \mathrm{mL})$.

Hydroxyl radicals formed by the reduction of hydrogen peroxide and radiation, significant contribution to molecular and cellular damage in biological systems. Therefore, prevention and scavenging of the formation of hydroxyl radicals is very important [31]. 
The hydroxyl radical scavenging properties of the test compound were investigated in order to determine antioxidant activity and the results are given in Table 4. It was determined that the test compound showed good activity at each concentration.

Figure 5 shows the radical inhibition percentages of the compound and standards. It can be inferred from the results that Hydroxyl radical scavenging activity of the test compound and standards ( $\alpha-$ tocopherol and BHT) increases with the increase of the concentration.

The hydroxyl radical scavenging activity of the test compound and standarts were in the following order at maximum concentration (250 $\mu \mathrm{g} / \mathrm{mL}):$ Bht $>$ Test compound $>\alpha$-tocopherol respectively.

Table 4. Hydroxyl radical scavenging activity of test compound, $\alpha$-tocopherol and BHT at different concentrations (50-100$250 \mu \mathrm{g} / \mathrm{mL})$.

\begin{tabular}{llll}
\hline Groups & $\mathbf{5 0} \boldsymbol{\mu g} / \mathbf{m L}$ & $\mathbf{1 0 0} \boldsymbol{\mu g} / \mathbf{m L}$ & $\mathbf{2 5 0} \boldsymbol{\mu g} / \mathbf{m L}$ \\
\hline Test Compound & $38,12 \pm 0.12$ & $80,10 \pm 1.49$ & $87,13 \pm 1.12$ \\
BHT & $37,25 \pm 1.46$ & $77,22 \pm 2.11$ & $88,42 \pm 2.19$ \\
$\alpha$-tocopherol & $43,12 \pm 2,01$ & $76,42 \pm 3,12$ & $82,14 \pm 2,52$ \\
\hline
\end{tabular}

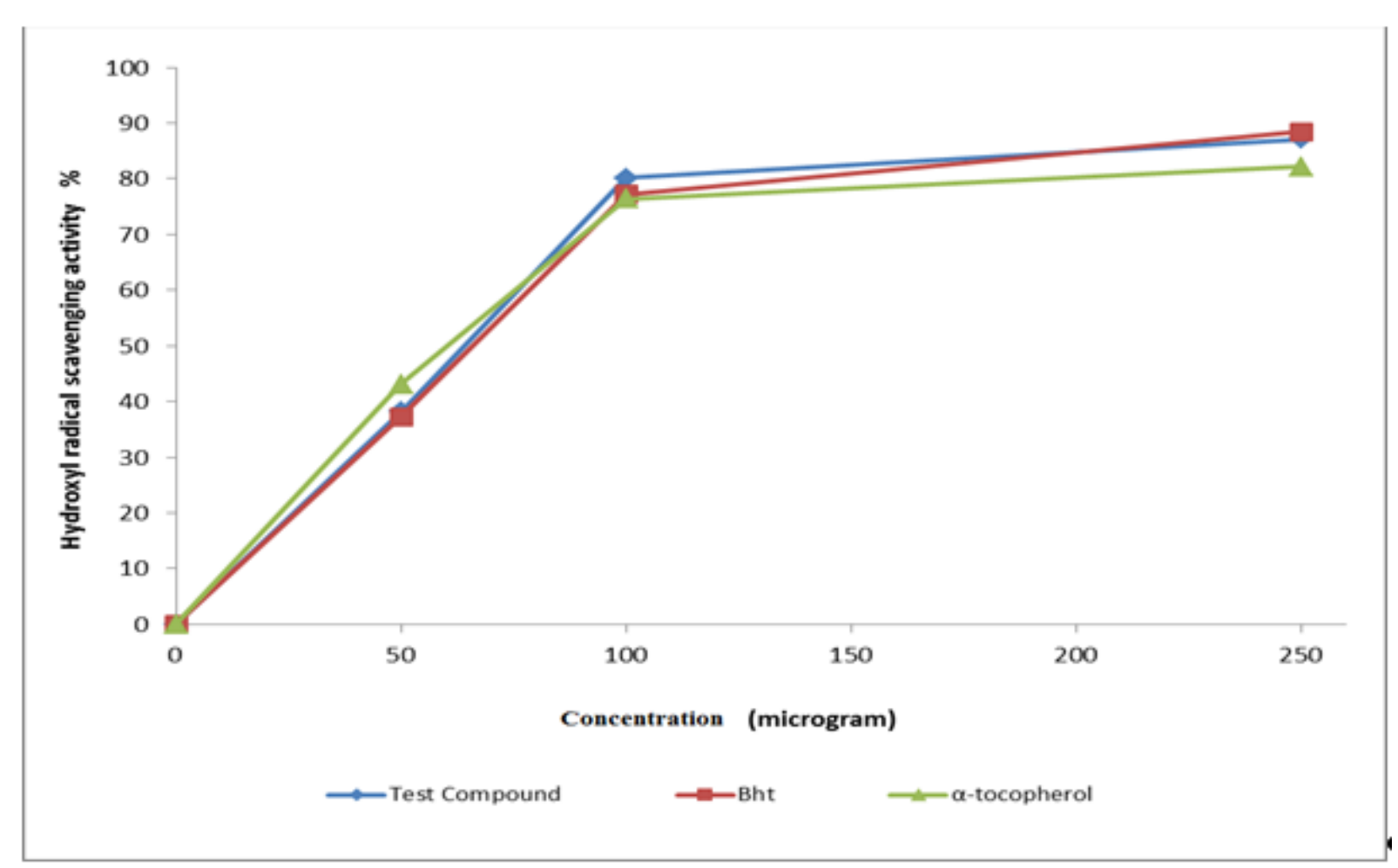

Figure 5. Comparison of Hydroxyl radical scavenging activity of test compound and standard antioxidant compounds such as BHT and $\alpha$-tocopherol, at the concentrations (50-100-250 $\mu \mathrm{g} / \mathrm{mL})$.

Since the compounds studied in the literature are different, it is not possible to make a complete comparison. In addition, while some test methods are used to determine the antioxidant properties of lipophilic species, some methods are used to determine the antioxidant properties of hydrophilic and / or lipophilic species [32].
In this study, we tried to determine the in vitro antioxidant capacity of the test compound using several different methods.

As a result of this study, first-time synthesized $(1 R, 2 R)-1,2$-bis-(5-(4-Hydroxynaphthalen-1ylazo)-[1,3,4]Thiadiazol-2-yl)-Ethane-1,2-Diol 
compound was found to show similar level of activity to that of the standard antioxidant BHT in all tests and possess both free radical scavenging and antioxidant capacity. Suggesting that the studied compound may be an antioxidant and antiradical source and should be used in different bio-activity tests this research provides a valuable contribution to the literature.

\section{ACKNOWLEDGEMENTS}

We thank Dr Metin Koparir for the gift of test compound.

\section{REFERENCES}

[1]. Genestra M., Oxyl radicals, redoxsensitive signalling cascades and antioxidants, Cell Signal, 19(9) (2007) 1807-1819.

[2]. Bagchi D., Bagchi M., Stohs S.J., Das D.K., Ray S.D., Kuszynski C.A., Joshi S.S, Pruess H.G., Free radicals and grape seed proanthocyanidin extract: Importance in human health and disease prevention, Toxicology, 148 (2000) 187197.

[3]. Datta K., Sinha S., Chattopadhyay P., Reactive oxygen species in health and disease. Natl Med J India., 13 (2000) 304-10.

[4]. Blois M. S., Antioxidant determinations by the use of a stable free radical. Nature, 26 (1958) 1119-1200.

[5]. Nagar R., Syntheses, characterization, and microbial activity of some transition metal complexes involving potentially active $\mathrm{O}$ and $\mathrm{N}$ donor heterocyclic ligands. J Inorg Biochem., 40 (1990) 349-356.

[6]. Cavigiolioa G., Benedettoa L., Boccaleria E., Colangelob D., Vianob I., Osellac D., Pt[II] complexes with different $\mathrm{N}$-donor aromatic ligands for specific inhibition of telmerase. Inorg Chim Acta., 305 (2000) 61-68.

[7]. Pires dos Santos M.L., Alairo A.F., Mangrich, A.S., Ferreira A.M.C., Antioxidant and Prooxidant Properties of some di-Schiff Base Copper(II) Complexes. J. of Inorg. Biochem. 71 (1998)71-78.

[8]. İkizler A., Hetero halkalı Bileşikler, Karadeniz Teknik Üniversitesi FenEdebiyat Fakültesi, (1985).Genel Yayın No: 84, Fakülte Yayın No: 38, Trabzon, 225-231, 243-245

[9]. Chapleo C.B., Myers M., Myers P.L., Saville J.F., Smith A.C.B., Stillings M.R., Tulloch I.F., Walter D.S., Welbourn A.P., Substituted 1,3,4-thiadiazoles with anticonvulsant activity. J Med Chem, 29 (1986) 2273-2280.

[10]. Palaska E., Şahin G., Kelicen P., Durlu N.T., Altinok G., Synthesis and antiinflammatory activity of 1acylthiosemicarbazides, 1,3,4-oxadiazoles, 1,3,4-thiadiazoles and 1,2,4-triazole-3thiones. Farmaco, 57 (2002) 101-110.

[11]. Gawande N.G., Shingare M.S., Synthesis of some thiazolyl-thiosemicarbazides, triazoles, oxadiazoles, thiadiazoles and their microbial activity, Ind J Chem, 26 (1987) 387-389.

[12]. Patel H.V., Fernandes P.S., Synthesis and biological activities of some substituted pyrazolylmethylene-1,2,4-triazoles, -1,3,4thiadiazoles and -1,3,4-oxadiazoles., J Ind Chem Soc, 67 (1990) 401-403.

[13]. Oral B., Rollas S., The synthesis and antitubercular activity of substituted hydrazone,2-pyrazoline-5-one and 2isoxazoline-5-one derivatives possessing 1,3,4-thiadiazole moiety, Marmara Pharm J, 16 (2012) 222-228.

[14]. Turner S., Myers M., Gadie B., Hale S.A., Horsley A., Nelson A.J., Pape R, Saville J.F., Doxey J.C., Berridge T.L., Antihypertensive thiadiazoles. 2. Vasodilator activity of some 2-aryl-5guanidino-1,3,4-thiadiazoles with., J Med Chem, 31 (1988) 906- 913.

[15]. Mhasalkar M.Y., Shah M.H., Nikam S.T., Further studies in substituted 4H-1,2,4Triazoles for Possible Hypoglycemic Activity. J Med Chem, 14(3) (1970) 260262. 
[16]. Rzeski W., Matysiak J., Szerszen M.K., Anticancer, neuroprotective activities and computational studies of 2-amino-1,3,4thiadiazole based compound., Bioorg Med Chem, 15 (2007) 3201-3207.

[17]. Ulusoy-Güzeldemirci N., Küçükbasmacı Ö., Synthesis and antimicrobial activity evaluation of new 1,2,4-triazoles and 1,3,4-thiadiazoles bearing imidazo[2,1b]thiazole moiety, Eur J Med Chem, 45 (2010) 63-68.

[18]. Koparir M,. Cansiz A,. Cetin A, and Kazaz C., Synthesis Of $(1 R, 2 R)-1,2-\mathrm{B} 1 \mathrm{~s}-(5-(4-$ Hydroxynaphthalen-1-Ylazo)-

[1,3,4]Thiadiazol-2-Yl)-Ethane-1,2-Diol, Chemistry of Natural Compounds, 41(5)(2005) .

[19]. Dinis T.C.P, Madeira V.M.C., Almeida L.M., Action of phenolic derivatives (acetaminophen, salicylate, and 5aminosalicylate) as inhibitors of membrane lipid peroxidation and as peroxyl radical scavengers, Arch. Biochem. Biophys., 315 (1994) 161-169.

[20]. Oyaizu M., Studies on products of browning reaction prepared from glucosamine, Jpn. Nutr. 44 (1986) $307-$ 316.

[21]. Halliwell B., Gutteridge J. M. C., Aruoma, O. I., The deoxyribose method: a simple test-tube assay for determination of rate constants for reactions of hydroxyl radicals, Analytical Biochemistry, 165 (1987) 215-219.

[22]. Edwin N.F., Huang S.W., Kanner J., Bruce German, J., Interfacial phenomena in the evaluation of antioxidants: bulk oils versus emulsions. J Agric Food Chem., 42(1994) 1054-1059.

[23]. Kolevai I.I., Van Beek T.A., Linssen J.P., De Groot A., Evstatieva L.N., Screening of plant extracts for antioxidant activity: a comparative study on three testing methods., Phytochem Anal., 13 (2002) 817.

[24]. Macdonald-Wicks L.K., Wood L.G., Garg M.L., Methodology For The Determination Of Biological Antioxidant Capacity İn
Vitro: A Review. J Sci Food Agric., 86 (2006) 2046-2056.

[25]. Scalzo R.L., Organic Acids İnfluence on DPPH Scavenging By Ascorbic Acid. Food Chem. 107 (2008) 40-43.

[26]. Meir S., Kanner J., Akiri B., Hadas S.P., Determination and involvement of aqueous reducing compounds in oxidative defense systems of various senescing leaves, J. Agri. Food. Chem., 43 (1995) 1813.

[27]. Chung Y.C., Chang C.T., Chao W.W., Lin C.F, Chou S.T., Antioxidative activity and safety of the $50 \%$ ethanolic extract from red bean fermented by Bacillus subtilis IMR-NK1,J. Agric. Food Chem., 50 (2002) 2454.

[28]. Yildirim A., Mavi A., Kara A.A., Determination of antioxidant and antimicrobial activities of Rumexcrispus L. extracts,J. Agri. Food. Chem. 49 (2001) 4083.

[29]. Yamaguchi F., Ariga T,. Yoshimira Y, Nakazawa H., Antioxidative and antiglycation activity of garcinol from garciniaindica fruit rind, Journal of Agricultural and Food Chemistry, 48 (2000) 180.

[30]. Finefrock A. E., Bush A. I., Doraiswamy P. M., Current status of metals as therapeutic targets in Alzheimer's disease, Journal of the American Geriatrics Society., 51 (2003) 1143.

[31]. Çiftci S.Y., Kelekçi N.G., Gökşen U.S., Uçar G., Free-Radical Scavenging Activities of 2-Benzoxazolinone Derivatives Containing Thiosemicarbazide, Triazole, Thiadiazole and Hydrazone Units, Hacettepe University Journal of the Faculty of Pharmacy, 31 (2011) 27-50.

[32]. Kulisic T., Radonic A., Katalinic V., Milos M., Use of different methods for testing antioxidative activity of oregano essential oil. Food Chem., 85 (2004) 633-640. 